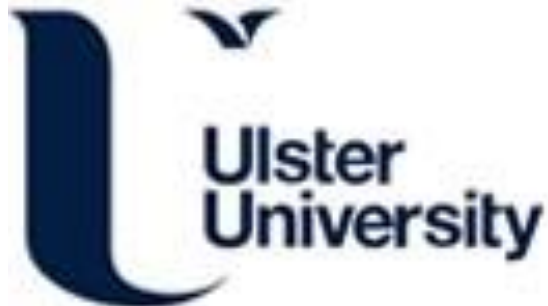

\section{Political commemoration and peacebuilding in ethno-national settings: the risk and utility of partisan memory}

Brown, K. (2018). Political commemoration and peacebuilding in ethno-national settings: the risk and utility of partisan memory. Peacebuilding, NA. [10.1080/21647259.2018.1491275]. https://doi.org/10.1080/21647259.2018.1491275

Link to publication record in Ulster University Research Portal

\section{Published in:}

Peacebuilding

Publication Status:

Published online: 18/07/2018

DOI:

10.1080/21647259.2018.1491275

\section{Document Version}

Author Accepted version

\section{General rights}

Copyright for the publications made accessible via Ulster University's Research Portal is retained by the author(s) and / or other copyright owners and it is a condition of accessing these publications that users recognise and abide by the legal requirements associated with these rights.

\section{Take down policy}

The Research Portal is Ulster University's institutional repository that provides access to Ulster's research outputs. Every effort has been made to ensure that content in the Research Portal does not infringe any person's rights, or applicable UK laws. If you discover content in the Research Portal that you believe breaches copyright or violates any law, please contact pure-support@ulster.ac.uk. 
Political Commemoration and Peacebuilding in Ethno-National Settings: The Risk and Utility of Partisan Memory

\section{Dr Kris Brown}

This is an Accepted Manuscript of an article published by Taylor \& Francis Group in Peacebuilding on June 15, 2018, available online:

http://www.tandfonline.com/10.1080/21647259.2018.1491275

DOI: $\underline{10.1080 / 21647259.2018 .1491275}$

Print ISSN: 2164-7259 Online ISSN: 2164-7267

Dr Kris Brown

Lecturer in Politics

School of Applied Social and Policy Sciences

University of Ulster

Jordanstown campus

Northern Ireland

BT37 0QB

Email: k.brown@ulster.ac.uk

Tel: + $44(0) 02890366199$

This research received funding from the UK Department of International Development:

Political Settlements Research Programme 


\begin{abstract}
This article examines partisan political commemorations and their impact on peacebuilding in ethno-national settings. It considers how commemoration can assume highly partisan, ideological frames working to exacerbate conflict but also argues that partisan forms of commemoration may be used in a more pragmatic, adaptive fashion that may underwrite peaceful politics. Whilst arguing this, the article notes that partisan commemoration can remain as a drag on peacebuilding, and so posits ways of counterbalancing this negative aspect, drawing on a case study examination of the 'Decade of Centenaries' in Northern Ireland. Proposals to facilitate adaptive commemoration, and foster activities that counter balance more partisan commemoration, are considered.
\end{abstract}

Keywords: Commemoration, Political Memory, Memorials, Peacebuilding, EthnoNationalism

\title{
Introduction
}

This paper examines the political commemoration of periods of violence and conflict as an important aspect of political activity that impacts on peacebuilding within ethno-national settings. Commemoration is understood as particularly important where the lines of fracture correspond to ethno-national identity.

The article examines how we can best understand and engage with forms of ethno-national commemoration, which are often distinctly partisan and one sided in their presentation of narratives of past conflict. The paper reasons that commemoration serves as a vital means to manage and maintain ethno-national constituencies during periods of peacebuilding- whether 
in a peace process or political 'unsettlement'. Using short illustrative case studies from Northern Ireland and Lebanon, the argument is advanced that partisan commemoration often displays two facets. Firstly, it can indeed act to underwrite militancy and militarism, effectively sharpening a symbolic conflict over the meaning of the past in the present. This may damage attempts at peacebuilding. Yet partisan commemoration can also display a second facet: it can promulgate a more pragmatic adaptation of these partisan forms of 'hot' memory, one which reframes them to underwrite more peaceful methods or environments, and attune key constituencies to necessary shifts in the political dispensation. This is conceptualised as adaptive commemoration.

Partisan commemoration may thus be Janus faced - at once helping to embed peace in important constituencies, whilst also hardening boundaries between groups with a history of enmity. These two facets are not mutually exclusive and can co-exist. The paper lastly considers how adaptive commemoration may be bolstered by a wider societal engagement with a critical-inclusive commemoration; one which may serve to partially defuse or mitigate political commemoration when it takes the form of a war by other means.

\section{Peace and the Importance of Commemoration in Deeply Divided Societies}

The political use of commemoration matters in societies emerging from conflict. A survey of case studies and more comparative research in ethno-nationally divided societies reveals that public memory work in relation to conflict is quite prolific. ${ }^{1}$ Politically partisan, ethno-

\footnotetext{
${ }^{1}$ Laleh Khalili, Heroes and Martyrs of Palestine: The Politics of National Commemoration (Cambridge: Cambridge University Press, 2007); Elisabetta Viggiani, Talking Stones: The Politics of Memorialization in Post-Conflict Northern Ireland. (Oxford: Berghahn Books, 2014); Mara Albrecht and Bassel Akar, The Power of Remembrance: Political Parties, Memory and Learning about the Past in Lebanon (Cologne: forumZFD, 2016); Yiannis
} 
nationalist, and often antagonistic, forms of commemoration predominate in such settings. ${ }^{2}$ More inclusive forms of commemoration and memorialisation do exist in divided societies, but they are distant competitors to the partisan. ${ }^{3}$ How much of this politically partisan commemoration accurately reflects the prevailing mood within deeply divided societies may be open to debate, and relatively few studies have attempted to gauge audience understanding of, and empathy with, such commemoration. Yet these commemorations are numerous, and can involve thousands of participants at one end of the scale, or at least display clear local rootedness at the smaller end. Levels of whole hearted support and engagement may vary, but support nevertheless appears significant and authentic; this is not simply the work of ethnic entrepreneurs pulling puppet strings, with their target constituencies responding mechanically.

This engagement with commemoration reflects the critical importance of group narratives in creating histories and fostering a sense of collective identity in ethno-national settings. ${ }^{4}$ Collective memory is particularly important in helping form a collective identity as it forges a shared sense of the past and common purpose by allowing the group to physically come

Papadakis, 'Nation, narrative and commemoration: Political ritual in divided Cyprus', History and Anthropology 14 (1), (2003): 253-270.

${ }^{2}$ Anna Di Lellio and Stephanie Schwandner-Sievers. 'Sacred Journey to a Nation: The Construction of a Shrine in Postwar Kosovo', Journeys 7 (1) (2006): 27-49; Kris Brown and Adrian Grant. 'A Lens Over Conflicted Memory: Surveying 'Troubles' Commemoration in Northern Ireland' Irish Political Studies 31 (1), (2016): 139-162; Craig Larkin, Memory and Conflict in Lebanon: Remembering and Forgetting the Past, ( London: Routledge, 2012)

${ }^{3}$ Balkan Insight, 'Conflicting Memories Post war Balkan Monuments in Focus'. http://www.balkaninsight.com/en/page/balkan-transitional-justice-memorialisationconflicting-memories. (Accessed 15 October 2017); Brown and Grant, 'A Lens Over Conflicted Memory: Surveying ‘Troubles’ Commemoration in Northern Ireland'.

${ }^{4}$ Marc Howard Ross, Culture and Belonging in Divided Societies: Contestation and Symbolic Landscapes (Philadelphia: University of Pennsylvania Press, 2012); Anthony D. Smith, The Power of Ethnic Traditions in the Modern World (Edinburgh: Edinburgh University Press, 2007) 
together as the group, by disseminating narratives that attempt to bind and guide, and by underwriting political positions with a sense of powerful, sacral emotion. The narratives within commemorations are organising myths; myths not in the sense of being wholly fictitious, but through being simplified guides to political understanding and action. These narratives, and their accompanying symbolism, become even more potent and politically useful in moments of change or crisis. ${ }^{5}$

Peace processing, transitions, or an 'unsettled' constitutional agreement, see moments of crisis and turbulence. Elites must sell compromises, bring along their base, and thwart splits, challengers and spoilers. Constructing a convincing and evocative narrative that supports their position, and then communicating it convincingly to their constituencies is key. Political commemorations are suitably resonant, and provide a ready-made audience of the faithful. Political commemoration, even of 'hot' periods of political violence, is also malleable. The polyvalence of commemorative material culture is not only high, but the repertoire of materials is itself vast. This gives commemoration a large adaptive capacity. As Olick notes ${ }^{6}$ collective memory can be usefully framed as 'a variety of products and practices' near infinite in type. The plethora of forms of practice is replicated in many settings of ethnonational conflict as can be seen from studies of the Basque country ${ }^{7}$, Northern Ireland ${ }^{8}$ and

\footnotetext{
${ }^{5}$ Stuart J Kaufman, Modern Hatreds: The Symbolic Politics of Ethnic War, (Ithaca, New York: Cornell University Press, 2001)

${ }^{6}$ Jeffrey K Olick, 'From Collective Memory to the Sociology of Mnemonic Practices and Products', 158 in Cultural Memory Studies: an International and Interdisciplinary Handbook ed. Astrid Erll, Ansgar Nünning, and Sara B. Young (Berlin: Walter de Gruyter. , 2008): 151-162.

${ }^{7}$ John P Linstroth, 'The Basque Conflict Globally Speaking: Material Culture, Media and Basque Identity in the Wider World', Oxford Development Studies 30 (2), (2002): 205-222.

${ }^{8}$ Brown and Grant, 'A Lens Over Conflicted Memory: Surveying 'Troubles'

Commemoration in Northern Ireland'
} 
Palestine ${ }^{9}$. Indeed, even a single communal actor, such as Hezbollah in Lebanon, can expand their memory products into a fully-fledged national and regional media strategy. ${ }^{10}$

This valued engagement with commemoration chimes with Kertzer's ${ }^{11}$ analysis that such political rituals foster a sense of higher political purpose, to be part of something important, meaningful and above the ordinary. When one is engaged in this process with other individuals, strong affective bonds are created, at least for a time. Kertzer goes so far as to say that political ritual is a necessary way of producing political solidarity. It is a valued political resource in that it provides a sense of common identification; it legitimises power relations between elites and grassroots constituencies (or serves to delegitimise rival leadership claims on a constituency); it can serve to produce strong emotive support or resistance to the state; and it can facilitate the creation or replenishment of new leaderships, as ritual is used to underwrite the legitimacy of a new 'top table'. ${ }^{12}$

As noted, commemoration as political ritual incorporates a high degree of symbolism. These often comprise 'condensation symbols' - illustrations and representations, words, phrases and maxims which evoke forceful values and thumbnail sketched narratives which serve as easily propagated concepts that can prime for action ${ }^{13}$. In ethno-national settings, these are defined as 'myth symbol complexes' - schemata that explain a groups values, interests, and fears by a narration of the past and use it as a compass to mobilisation in the present and future. As

\footnotetext{
${ }^{9}$ Khalili, Heroes and Martyrs of Palestine: The Politics of National Commemoration ${ }^{10}$ Paula Schmitt, Advertised to Death: Lebanese Poster Boys (Beirut: Paula Schmitt, 2009); Lina Khatib, Dina Matar, and Atef Alshaer, The Hizbullah Phenomenon: Politics and Communication (Oxford: Oxford University Press, 2014)

${ }^{11}$ David I. Kertzer, Ritual, Politics, and Power. (New Haven:Yale University Press, 1988)

${ }^{12}$ Kertzer, Ritual, Politics and Power, 169-177

${ }^{13}$ David S. Kaufer, and Kathleen M. Carley. 'Condensation Symbols: Their Variety and Rhetorical Function in Political Discourse', Philosophy \& Rhetoric 26 (3), (1993): 201-226.
} 
Kaufman notes, this makes them useful templates for ethnic entrepreneurs to attempt to bind communities to a particular course of action, often one of conflict. ${ }^{14}$ Indeed, such condensation symbols are particularly useful in times of widespread social change and power shifts, but not always as an impetus to upheaval. Condensation symbols allow communities to 'drop their heaviest cultural anchors' and thus provide a potentially stabilising influence. ${ }^{15}$

\section{Partisan Commemoration - A Form of War or Adaptation to Peace?}

Still, the nature and utility of partisan commemoration in ethno-national societies has been open to interpretation. One analysis emphasises that partisan commemoration essentially comprises a 'war by other means'. This may take a very direct form, such as when commemoration is used to delegitimise the values, actions and standing of an ethno-national opponent group, whilst promoting the values, action and standing of one's own group. ${ }^{16}$ Commemoration thus validates political claims making in the present. Commemoration can also be used to assert or demonstrate power and control in a geographic area, be it local neighbourhood or the state itself. ${ }^{17}$

These interpretations have accuracy and value, but do not reflect all the important facets of ethno-national commemoration. Other research has brought to light an adaptive role that communal commemoration can play in ethno-national societies. Conway has shown how commemoration of the Bloody Sunday massacre had expanded in a series of phases away

\footnotetext{
${ }^{14}$ Kaufman, Modern Hatreds: The Symbolic Politics of Ethnic War

${ }^{15}$ Anthony Cohen, The Symbolic Construction of Community (Chichester: Ellis Horwood, 1985),101-102

${ }^{16}$ Sara McDowell and Máire Braniff. Commemoration as Conflict: Space, Memory and Identity in Peace Processes (Basingstoke: Palgrave Macmillan, 2014)

${ }^{17}$ Sara McDowell, "Armalite, the Ballot Box and Memorialization: Sinn Féin and the State in post-Conflict Northern Ireland', The Round Table 96(393), (2007): 725-738.
} 
from an exclusively ethno-nationalist frame, whilst still remaining rooted in local, highly segregated communities. ${ }^{18}$ Khalili has examined a shift in Palestinian commemorative form and discourse which has accentuated notions of human rights and a suffering, civilian, victimhood whilst maintaining a divergent commemoration of armed resistance. ${ }^{19}$ A similar process is observable within commemoration amongst the Tamil diaspora. ${ }^{20}$ Turning to Lebanon, Volk has noted that the commemorations within a particular sect's territory and organised by its own confessional elite, have sometimes been re-framed to include another 'out' group, or evoke an over-arching, inclusive national identity. ${ }^{21}$

Studies like the above have thus highlighted an undercurrent within partisan commemoration, one which partially recalibrates conflict narratives, nuances political messaging yet also works to maintain group cohesion in a changing political scene. We can better unpack this tension within partisan commemoration, often antagonistic to inclusive form of memory but also adaptive to, and supportive of peace by examining the cases of Lebanon and Northern Ireland.

\section{Two Case Studies - Understanding the Uses of Partisan Commemoration}

In order to examine partisan forms of political commemoration in more detail and tease out its implications, two short case studies may serve as illustrative examples of the processes at work. Each case study, examining political commemoration in Lebanon, and within Irish Republicanism in Northern Ireland, discusses the means by which commemoration serves to

\footnotetext{
${ }^{18}$ Brian Conway, 'Rethinking Difficult Pasts: Bloody Sunday (1972) as a Case Study'. Cultural Sociology 3 (3),(2009): 397-413.

${ }^{19}$ Khalili, Heroes and Martyrs of Palestine

${ }^{20}$ Tom O'Neill, 'In the Path of Heroes: Second-Generation Tamil-Canadians after the LTTE." Identities 22 (1), (2015): 124-139.

${ }^{21}$ Lucia Volk, Memorials and Martyrs in Modern Lebanon. (Bloomington: Indiana University Press, 2010
} 
ideologise conflict and foster cohesion within groups, and also maintain boundaries between groups. Our focus then moves on to examine how commemoration by ethnic partisans can also shift to pragmatically adapt to more peaceful forms of political interaction and claims making, effectively using the memory of conflict to guide their constituents in time of peace. The twin cases of Lebanon and Northern Ireland are deliberately selected to highlight how partisan commemoration can adjust its narrative framing and evolve more nuanced approaches to different political dispensations. There is no insinuation that such evolution is a universal phenomenon across all types of ethno-national commemoration; but the regional spread of the ethno-nationalisms and conflicts, emerging from western Europe and the Middle East, shows that this process of adaptation can cut across different political cultures. We turn first to commemoration as a force which underwrites divisions between groups, amplifying themes of militancy, martyrdom and militarism, using Lebanon as the first example.

\section{Partisan Commemoration as Cementing Conflict}

The ideological uses of partisan ethnic memory in a divided society such as Lebanon can be readily articulated. In a society in which politics is organised on a confessional ethnoreligious basis, commemoration acts as part of the foundations for political identity. Through its construction of binding narratives and its reification of the community by physically bringing the group together as the group, commemoration works to foster strong in group attachment and create boundaries with any 'out' groups. Ethno-religious commemoration thus mitigates the twin threats of apathy and non-sectarian identification which may inhibit a confessional party's political strength. Commemorating martyrs is particularly powerful as martyrdom is seen to give credibility and legitimacy to the political parties' worldviews. The 
symbolic value of the martyr lies in a claim of heroism and steadfastness, and has proved a currency that Lebanese parties strived to display. ${ }^{22}$ It also provides present day strength by constructing a line of continuity with the past; the values of those martyred remains true to ideological core of the political party in the present - thus the party appears resolute, morally driven, and authentic. It shows its historical roots, allowing it to portray itself as embedded in its constituency, as something more than a political party with all the baggage of horse trading and cynicism that may accompany that label. Martyrdom, a concept and status which combines heroism, bearing witness, and victimhood in one package, is also highly useful in adjusting difficult narratives. Parties have employed the commemoration of martyrs to reframe their losses on the battlefield, whether a literal battlefield or a political contest. Amongst Lebanese ethno-religious parties the invocation of the martyr can enable a claim to moral victory, even if a political loss to a communal 'other' is apparent. ${ }^{23}$ Commemoration also allows a very practical demonstration of political power; large, well-attended commemorations which create 'spectacles' via stagecraft and powerful use of symbols shows strength and publicly stages the party as a powerful actor in the political field.

Commemoration further serves to legitimise one's present policies by invoking success (past victories) and commitment (past sacrifice). In Lebanon, such a valuable legitimising theme emerges in the concept of 'resistance'. Groups compete for the title of 'resistance', and for the right to define what 'resistance' is. Hezbollah organises a regular and resource heavy calendar of commemoration which helps defend and define the groups 'resistance' project and its current maintenance of an armed organisation. ${ }^{24}$ Other parties, such as the Christian Lebanese Forces, Kata'eb or the Sunni Future Movement use their own commemorations to

\footnotetext{
${ }^{22}$ Yasmine Dabbous, Khaled Nasser, and Farah Dabbous. “ "Across the Bridge of Death" The Culture of Martyrdom in Lebanon 1960s-1980s', International Journal of Cultural Studies 13 (6), (2010): 593-615.

${ }^{23}$ Ibid.

${ }^{24}$ Albrecht and Akar, The Power of Remembrance, 27.
} 
challenge Hezbollah for the title of the true resistance, and de-legitimise its usurpation of the state's monopoly on the use of force. Aside from definitional and legitimacy contests, Hezbollah's commemoration has an additional role: one of suffusing a strong sense of ethnoreligious belonging and cementing a boundary between them and other communities; commemoration forms a facet of their wider strategy for creating an Islamic milieu, that will saturate the political, social and cultural sphere of the Shi'a community. ${ }^{25}$

Party political commemoration can serve as a highly partisan ideological instrument in Northern Ireland too. ${ }^{26}$ Although commemorations of the more recent 'Troubles' may be organised by a great number of organisation types and private individuals or families, Irish Republican and Ulster Loyalist commemorations tend to predominate, and are strongly attached to parties, political associations, and groups of former or current paramilitaries. ${ }^{27}$ Those who attend or spectate at such commemorations, extend beyond party members or close political affiliates. Given that commemorations, of whatever size, usually take place in areas of local political support, this is hardly surprising. Small neighbourhood commemorations may only attract a few dozen of spectators, but larger proceedings that commemorate highly important individuals and events see thousands taking part, and thousands more spectating. Taking Irish Republicanism as an example, we can see how commemorative narratives seek to construct legitimacy by linking to earlier forms of separatist violence. These narratives ground their ideological project in sanctified history by

\footnotetext{
${ }^{25}$ Lara Deeb and Mona Harb. 'Politics, Culture, Religion: How Hizbullah is Constructing an Islamic Milieu in Lebanon', Review of Middle East Studies 43 (2) (2009): 198-206.

${ }^{26}$ Analysis of Irish Republican commemoration in this section is largely based on field observation of public commemorative activity (60+ events) from 2006 to the present.

${ }^{27}$ Brown and Grant, 'A Lens Over Conflicted Memory: Surveying 'Troubles' Commemoration in Northern Ireland'
} 
demonstrating or constructing links with earlier iterations of struggle, espoused as wars of liberation, many of which are themselves now legitimised by official commemorations in the independent Irish state. Republican violence in the modern 'Troubles' is then narrated in text, speech, or symbol as a 'war' itself, and merely the latest expression of past conflicts. Former paramilitaries of the more recent 'Troubles' are feted, and projected as ordinary people who showed extraordinary commitment and courage, and thus worthy of emulation. This is an important activity, as through the course of these 'Troubles' republican violence was labelled by most political actors, including both the UK and Ireland, as terrorism. Republicans chafed at this criminalisation and devoted considerable resources of time and energy in countering it during the conflict; this process continues even as they have now abjured violence and enjoyed remarkable political success (and elite acceptance) in Ireland North and South.

Claims of legitimacy for past action are further augmented by narratives, and sometimes theatre or street theatre, which depicts injustice perpetrated against Republicans and the wider Nationalist community in the form of repression by the security forces, an unjust criminal justice system, and state sponsored assassination. This street theatre can often incorporate more militant imagery, one of men and women carrying replica weaponry representing an armed paramilitary response to this perceived injustice. ${ }^{28}$ The communal 'other' -the Unionist and Loyalist communities- are not always foregrounded in commemorations but when they are, their political expressions may be presented in terms of hostility and threat. Commemoration seeks further legitimacy for the current Republican project, not simply by invoking icons of national history, and not just by spotlighting the memory of past injustices emerging from an 'out' group, but by constructing narratives of popular support and local rootedness. ${ }^{29}$ Republican commemorations stress the regeneration of post 1969

\footnotetext{
${ }^{28}$ Brown and Grant, 'Lens over Conflicted Memory', 152-153.

${ }^{29}$ McDowell, 'Armalite and Ballot Box'.
} 
republicanism as a popular reaction emerging from injustice, discrimination and repressive security measures. In short, it is rooted not just in history and the mythologies of nationalism but from the 'peoples' experiences themselves. Thus, Republican violence becomes communal defence and defiance as well as national liberation; the maintenance of a continued unity between the people and the now purely political project of Republicanism is narrated as being necessary, efficacious and a natural evolution. The methods change: but commemorations teach that the goals, values, and the need for a continued unity remain constants. ${ }^{30}$ In narrating and commemorating a period of political violence, themes of legitimacy, historical continuity, and the binding of the communal group are thus woven together. These themes aim to cohere the group and its identity, and support the rightfulness of contemporary group actions and values, in the present.

\section{Partisan Commemoration as Pragmatic Adaptation to Peace}

Yet, the partisan commemoration of periods of political violence do not simply act as a 'war by other means', ideologizing and fixing conflict memory. Irish Republicanism commemoration by Sinn Féin, the largest republican party, has incorporated narratives and messaging within its commemorative practice which may be construed as a more pragmatic adaptation to the new political dispensation over the last decade. It has achieved great electoral success, but has also been faced with the ideological problem of administering Northern Ireland as part of the British state, something deemed anathema before the outworking of the Northern Ireland peace. This group's commemorative activity in relation to the modern 'Troubles' is energetic, numerous, and often closely connected to, and within, local neighbourhoods of support. As such, it represents a very effective means of messaging

\footnotetext{
${ }^{30}$ Kevin Bean, The New Politics of Sinn Féin. (Liverpool: Liverpool University Press, 2007):126
} 
to its political constituency; one that seeks to chart new political courses, and to mitigate doubts and fears, whilst simultaneously reassuring constituents of the continuity of its political values. For Irish Republicans, memorialisation has demonstrated a remarkable political utility. The very act of commemorating and indeed celebrating past fighters and activists stresses the ideological commitment of the leadership to the overall political project; they have not forgotten where the political project came from (the streets and rural townlands), its core values of resistance and eventual goal of national unity. ${ }^{31}$ Rather than simply being an ideological deadweight, inhibiting political compromise, the dead and the memory of campaigns of violence are used as a symbolic ballast, serving to steady the movement's political re-calibration to peace. Any disjuncture of remembering militant violence whilst advocating peaceful politics is avoided by reframing the 'armed struggle' as a distinct phase that is now superseded: Messages in commemorations have projected politics as a new phase of the struggle for Irish unity; the purely political arena is thus a proper, natural and appropriate continuation of the struggle. The continuity that is crafted between the dead and the living is not one of militant means, but of political goals, commitment and values.

\section{A Republican Commemoration - Continuity, Adaptivity and Pragmatism}

The 2006 Hunger Strike commemoration organised by Sinn Féin to remember the $25^{\text {th }}$ anniversary of the 10 men who died in a prison fast against the terms of their imprisonment, offers a good example of this narrative process. ${ }^{32}$ The form and spectacle of the commemoration has remained broadly the same in later years. This instance also took place at a time in the peace process when Republicanism was moving towards a recalibrated

\footnotetext{
${ }^{31}$ Brown and Grant, 'A Lens over Conflicted Memory'; Elisabetta Viggiani, Talking stones: the politics of memorialization in post-conflit Northern Ireland. (Oxford: Berghahn, 2015)

${ }^{32}$ Field notes, west Belfast, $13^{\text {th }}$ August 2006
} 
political agreement which would see them accept policing and criminal justice structures for the first time, and share power with a more 'hard line' variant of Unionism. The commemoration itself can be divided into two halves. The first saw a march of Sinn Féin supporters towards the Casement Park sporting grounds in west Belfast. Many colourful Irish Republican flute bands took part and the various Sinn Féin cumainn (party branches) carried banners picturing Irish Republican Army (IRA) members killed in the more recent conflict, or historical figures associated with earlier periods of violence. The remembered individuals are sometimes pictured in uniform or with weaponry. As the parade passed many spectators stepped off the pavement to fall in behind and become a part of the procession. As the march proceeds, the narration unfolds in a series of tableaux vivant or pieces of street theatre. This narrative depicts the vicissitudes of IRA activism, and that of the hungers strikers particularly. These scenes and representations portrayed house raids by the security forces, interrogation by the Police, trial and conviction, incarceration and protest, hospitalization on hunger strike, and ultimately death and communal mourning. Some scenes seek to inspire not only pathos or anger, but also derision. In one scene representing criminal justice, an actor in a comically outsize British judge's regalia repeatedly bangs his gavel and berates the crowd for their disloyalty and opposition to British rule. Puppet strings suspend from his waving arms.

The second part of the commemoration saw a concluding rally take place in sporting grounds, professionally equipped with address system, electronic screen and temporary stage. Thousands were in attendance, and most clapped and cheered to the sight of hundreds of former IRA prisoners parading into the venue and forming a military style column in the centre of the field. Gerry Adams, the Sinn Féin President at that time, made the keynote speech which deftly drew together the threads of Republican continuity and transformation, and resistance and negotiation. Adams reminded the audience that the IRA were threaded 
through that Republican constituency; they were 'the people sitting close to you' not an historical abstract. Yet militarism was quite absent from the messaging. Quotations from the iconic hunger striker Bobby Sands were used to argue the need for 'strategic compromises' in the future; indeed strategic thinking and political engagement were important themes of the speech. The hunger strikers were invoked as exemplars of shrewd political analysis, planning, and of the need to remain unified through challenging political action. As such, they became guiding lights for a transforming Irish Republicanism. Simultaneously, their sacrifice was imagined as being in a direct line of continuity with past heroes of previous struggles. History now served as a compass point to future political re-orientation. The political values of the hunger strikes were presented as being still imprinted on the Sinn Féin; For Adams, their powerful memory was imagined as ever present in the ongoing political process, 'keeping us [Republican leaders] right' in negotiations with the British. As powerful, yet malleable symbols, the Republican dead can thus be used to underwrite Republican compromise and transformation.

Counterintuitively, the energetic remembrance of political violence and martyrdom thus becomes a way of validating ideological shifts and political compromise. This memory of violence is not always shied away from; indeed, it often emerges in nostalgic tales of shared comradeship and 'derring-do' during eulogies. On some occasions the campaign of violence is narrated as having gone as far as it could realistically go, and that peaceful politics was the only avenue left open to pursuing Republican goals. ${ }^{33}$ The theme of the withering of the 'Orange state' is a strong one in commemorations, and clearly there is a wish to communicate to their constituency what the movement has banked, both through militant mobilisation in the past, and through an electoral success in the present which has propelled it into government in a power sharing executive. Again, the message is thus of continuity and

\footnotetext{
${ }^{33}$ Field notes from Lenadoon Martyrs Commemoration, 29 September 2012.
} 
banking successes, on the path to eventual unification; commemoration serves to reassure that goals and values remain the same, and that new strategies are achieving success, even as ideological shifts have taken place. ${ }^{34}$ Commemoration also allows mainstream Republicanism to hold the memory of the dead, a valuable political symbol, close to their own political project, and away from 'usurping' spoiler groups engaged in violence. Indeed, Sinn Féin leaders have used eulogies to de-legitimise what they term 'micro-groups' and fend off their claims to appropriate useful martyrs and histories.

At times, their commemoration can even be used to validate a more reflective position in relation to the memory of political violence. During a commemoration of the 'Battle of Ballymacarrett', a riot and gun battle at a communal interface, Sinn Féin President Gerry Adams said that commemorations in relation the forthcoming 'Decade of Centenaries' could become reflective and a means towards historically informed identities:

...there is an opportunity as we approach these [centenaries] to reach out, to open up dialogue about the future of the people of this island...and unionists might have a different view and that's ok... after decades of war each of us can share, and empathise, with those who have been hurt, we're very mindful, were not here triumphalistically [sic] we're here very mindful, when we remember our patriot dead of the hurt we have inflicted on others...our society is in a different place than it was forty years ago. ${ }^{35}$

This statement sits at a rhetorical level within the Republican approach to commemoration; their commemorations have not become spaces to debate 'armed struggle' or give voice to its victims. We might hardly expect that given the sacral and validating nature of commemoration as a political ritual. Yet it does serve as a signal to the Republican base that there are different interpretations and allegiances within memory and political identity, which cannot be ignored. Such assertations have continued at commemorations over recent years;

\footnotetext{
${ }^{34}$ Brown and Grant, 'A Lens over Conflicted Memory'.

${ }^{35}$ Field notes of public speech by Gerry Adams at Battle of Ballymacarret Commemoration, Belfast 20 June 2010
} 
Michelle O'Neill, the current President of Sinn Féin asserted at the 2018 Easter Rising commemoration that

Republicans and Unionists have conflicting narratives, conflicting histories and conflicting allegiances. That's the reality. Part of the journey to reconciliation is about recognising that to be the case. Much hurt has been caused, and real pain inflicted on all sides of the community. It takes time to heal those wounds and to build a new society together where we all respect each other. ${ }^{36}$

This may not be a venue which provides particularly effective outreach, but it does send a message about difficult and diverging narratives direct to the Republican base.

The partisan commemoration of periods of political violence in Lebanon also exhibits an adaptive aspect that expresses sentiments of cross communal rapprochement.

Commemoration has been used to cross sectarian boundaries and demonstrate solidarity between Christian and Muslim at memorials sites such as the Amal party controlled Qana memorial in southern Lebanon, and also in Beirut's Martyrs Square. ${ }^{37}$ Samir Geagea, head of the Maronite Lebanese Forces has used the annual Lebanese Forces Martyrs Mass, a vast commemorative gathering that incorporates a high degree of spectacle, not only to venerate and invoke their martyrs of the civil war, but also to apologise for excesses that the Lebanese Forces may have committed and to ask forgiveness from those they had harmed. ${ }^{38}$ A similar process of publicly critical reflection has been undertaken by Druze leader Walid Jumblatt of the Progressive Socialist Party. ${ }^{39}$

\footnotetext{
${ }^{36}$ Field Notes, west Belfast $1^{\text {st }}$ April 2018

${ }^{37}$ Volk, Memorials and Martyrs in Lebanon

${ }^{38}$ Now! Lebanon, 'Geageas' Speech Meets with Praise from President and PM' (22 Sept 2008).https://now.mmedia.me/lb/en/archive/geageas_speech_meets_with_praise_from_presid ent_and_pm_franjieh_and_aoun_to_respond_toda (accessed 15 Sept 2017)

${ }^{39}$ Albrecht and Akar, The Power of Remembrance, 35.
} 
Druze-Christian conflict memory is of some importance. The Druze-Christian conflict known as the 'Mountain War' saw extensive communal blood-letting, and the ethnic cleansing of the Christian community from the Chouf mountain region. An intensely bitter memory of sectarian conflict, it is now used as a platform for a process of 'Mountain Reconciliation' between Druze and Christian political partisans. ${ }^{40}$ Indeed, leaders of Druze and Christian parties have attended services together. This process began with the visit of Maronite Patriarch Sfier to the region in 2001, and since then Druze and Christian party leaders have engaged in a process of commemoration of this event to aid reconciliation and foster the return of former Christian residents. During events commemorating the Mountain War, and Sfier's reconciliatory visit, Geagea has referred to the mountain war as an 'absurd war' that should never have happened; rival Christian leader Michel Aoun has called for the building of memorials to the dead of all sects, effectively viewing 'Mountain Reconciliation' as a model for wider Lebanese rapprochement through mutual respect for each community's dead, and using the collective memory of the conflict to take a warning from history:

To revive our collective memory, to clear our conscience, and to draw lessons for the future, I call on our people in Mount Lebanon and in all the Lebanese regions to establish in their own cities and towns a commemorative monument holding the names of their martyrs, all of their martyrs, wherever and however they fell. And let this day of every year be the day where the Lebanese people visit these monuments and pray for the souls of their martyrs asking for their forgiveness and promising them never to go back to civil strife. The ability to revive the memory, to clear the conscience, to draw lessons, and the courage it takes to ask for forgiveness from these martyrs is the measure of one's ability to live in a safe, constructive, and secure community. This is the challenge that faces us today, so let's meet it in front of ourselves and the whole world. ${ }^{41}$

\footnotetext{
${ }^{40}$ Aïda Kanafani-Zahar , 'Displacement, Return And Reconciliation In Mount Lebanon', Accord, (24)7, (2012): 46-48.

${ }^{41}$ Michel Aoun, 'General Micheal Aoun Speech at Beiteddine Celebration' http://tayyar1989.blogspot.co.uk/2010/02/historic-mountain-reconciliation.html (22 Feb 2010) Accessed 15 Sept 2017.
} 
These processes represent progress, and commemoration is clearly being used by elites to signal a reconciliatory impulse to the political base, as well as to other confessional parties. Yet, there should be caution too. Geagea's apology was framed within an understanding that his militiamen were undertaking their 'national duty' during the conflict and that the 'exploitation' of their admitted mistakes for present political purposes should stop. ${ }^{42}$ Clearly, partisan commemorative outreach is limited by the need to maintain the overall legitimacy of one's own movement in the past, and through the memory of that, in the present too.

In the Lebanese context commemoration is used to create a sense of political solidarity between certain confessional parties. Since the independence intifada (The 'Cedar Spring' of 2005), sectarian politics has exhibited a gravitational pull towards two camps: the March $14^{\text {th }}$ alliance (now comprising the Future Movement (largely Sunni), the Kata'eb (largely Christian) and the Lebanese Forces (Christian). In opposition is the pro-Syrian March $8^{\text {th }}$ bloc; comprising Amal (Shia), Free Patriotic Movement (largely Christian), Hezbollah (Shia), the Marada movement (Christian) and the Syrian Socialist Nationalist Party (non-sectarian but with strong links to the Greek Orthodox). The Druze Progressive Socialist Party has oscillated between the two camps over time. Party organisation remains confessional, but the necessity of building alliances that further both particular communal interests, and shared goals, necessitates the formation of a sense of solidarity and commonality in the present, and which may be projected to the future. This is not easy given a history of sectarian bloodletting during the Lebanese civil war. Yet, commemoration of past acts of violence, in the

\footnotetext{
${ }^{42}$ Daily Star [Beirut], 'Geagea Marks Anniversary of Mountain Reconciliation, Calls for Solidarity’, (4 Aug 2016)
} 
form of martyrdom, has proved a useful mechanism in creating a shared sense of belonging between confessional parties.

The memory of the assassinated Future Movement leader Rafik Hariri has proved particularly powerful in this regard. ${ }^{43}$ Statuary, monuments and a large tomb housing Hariri's remains are powerful sites of memory in downtown Beirut and complimenting this is a large annual commemoration bringing together not simply the supporters of the Future Movement, but leaders and followers of the other parties (predominantly Christian) which together form the March $14^{\text {th }}$ bloc. An important facet of Hariri's memory is that he has become a symbol of March $14^{\text {th }}$ in toto, and more than that, a symbol of independent nationhood. His commemorations can thus help construct a sense of overarching national identity that is often weakened and undermined by confessional identification and political organisation. Christian and Sunni politicians send messages of solidarity, shared goals, and the commonality of shared national fealty at his commemorations. ${ }^{44}$ Hariri is a recent martyr, and his political positions prior to his assassination enable a seamless weaving into current March $14^{\text {th }}$ narratives of solidarity.

Interestingly, another martyr is also invoked, one whose death occurred during the civil war and who predated the cross confessional alliance of the 'Cedar Spring'. Bashir Gemayel, the venerated Christian Maronite political and militia leader, has also been presented in commemorations and public memory as a 'forefather of March $14^{\text {th }}$, not simply by the

\footnotetext{
${ }^{43}$ Ward Vloeberghs, 'Worshipping the Martyr President: the Darīh of Rafiq Hariri in Beirut' in Ethnographies of Islam: Ritual Performances and Everyday Practices, ed. Baudouin Dupret, Thomas Pierret, Paulo G. Pinto, and Kathryn Spellman-Poots (Edinburgh: Edinburgh University Press 2012): 80-93.

${ }^{44}$ Ward Vloeberghs, 'The Making of a Martyr. Forging Rafik Hariri's Symbolic Legacy' in Lebanon after the Cedar Revolution, ed. Are J. Knudsen and Michael Kerr (London: Hurst, 2012): 163-183.
} 
affiliated Christian parties, but by all parties within the March $14^{\text {th }}$ bloc. ${ }^{45}$ Media related to the Hariri political family has also celebrated his memory in this way. This may at first seem strange; Gemayel was after all the leader of a sectarian faction, politically and militarily, in a communal civil war which saw much Maronite Christian and Sunni Muslim mutual conflict and victimisation. Yet, his memory invokes similarities with the more modern commemoration of Hariri. He was ardent in his support of a Lebanese identity and Lebanese sovereignty; and he too was assassinated by political forces which were understood to be hostile to the exercise of sovereignty by that state. A Christian partisan of the civil war is thus linked to the Sunni moderniser of the post war era; although different in background they are presented as having strong similarities that serve to unite different confessional groups in the present: They held respected high office, they wished for a strong and sovereign Lebanon, and they were both martyred by the enemies of that goal.

The pragmatic use of communal memory is also a feature of Hezbollah's programme of commemoration. Certainly, Hezbollah's use of public memory reflects communal concerns (projecting the power of the Shia community, creating a public sphere of Islamic identity, and outbidding its Shia competitor for political support). However, it has also crafted commemoration of 'resistance' to complement moves towards 'Lebanonisation', even if that remains only a partial shift. ${ }^{46}$ Hezbollah has also used the memory of the 'resistance' to establish credibility and legitimacy for itself as an authentically Lebanese entity - one whose

\footnotetext{
${ }^{45}$ Sune Haugbolle, 'The Secular Saint: Iconography and Ideology in the Cult of Bashir Jumayil', in Andreas Bandak and Mikkel Bille, ed. Politics of Worship in the Contemporary Middle East: Sainthood in Fragile States ( Leiden: Brill, 2013): 191-212 ${ }^{46}$ Augustus Richard Norton, Hezbollah: A Short History (Princeton: Princeton University Press, 2014); Krista E. Wiegand, 'Reformation of a Terrorist Group: Hezbollah as a Lebanese Political Party', Studies in Conflict \& Terrorism 32 (8), (2009): 669-680; Robert G Rabil, 'Hezbollah, the Islamic Association and Lebanon's Confessional System al-Infitah and Lebanonization', The Levantine Review 1(1), (2012): 49-67; Magnus Ranstorp,'The Strategy and Tactics of Hizballah's current "Lebanonization process" ', Mediterranean Politics 3(1), (1998): 103-134.
} 
purpose is to protect the state from the Israeli threat and not to act primarily as a communal militia, a state within a state, or foreign surrogate, all charges which have been made by the March $14^{\text {th }}$ bloc (frequently during their own commemorations). The extensive museum complex at Mleeta, the 'Spider's Web' temporary exhibition in the southern suburbs of Beirut, billboard commemorative posters, and commemorative speeches by Hezbollah leader Hassan Nasrallah have each played to aspects of this 'Lebanonisation'. As well as deflecting the charges brought by their March $14^{\text {th }}$ rivals, it may also help to mollify Hezbollah's Christian allies that its guns will not be turned on the Lebanese, and that it too values a Lebanese identity and sovereign state.

Whilst communal memory can be pragmatically remodelled to project a cross communal flavour, it nevertheless retains a deeply ingrained communal core. In short, its most important component remains its ability to bind a communal group and provide appropriate narratives and symbols. The principle value of Gemayel's memory is to project a 'muscular Maronitism ${ }^{47}$ for Christian political parties, a public memory which evokes strength and optimism for a group which has been politically weakened and feels a certain political disenchantment in the present. The public memory of Hariri too has seen a partial re sectarianisation, as Sunni symbolism edges out more cross confessional invocation. ${ }^{48}$ Despite 'Lebanonisation', Hezbollah's commemoration remains largely centred on its building of an Islamic 'milieu'. Yet, the ability of communal memory to adapt to a cross communal form remains noteworthy and has served as a pragmatic political mechanism of alliance building and communication between confessional sects.

Rethinking Partisan Memory-Conceptualising Adaptive Commemoration

\footnotetext{
${ }^{47}$ Haugbolle, 'The Secular Saint: Iconography and Ideology in the Cult of Bashir Jumayil' ${ }^{48}$ Vloeberghs, 'Worshipping the Martyr President', 87-90
} 
Daniel Bar-Tal has offered the analysis, based on extensive research in Israel and Palestine, that processes of commemoration simply act to constantly regenerate narratives which sharpen boundaries and harden animosities. As such they become 'concrete investments' for political actors and their publics to continue peace inhibiting struggle

...in times of conflict, and especially intractable conflict, rituals and ceremonies contribute to the continuation of the conflict. Their contents fuel public animosity towards the enemy while urging the society's members to fulfil their patriotic duties in the conflict. As such, they serve as an important socialisation and cultural factor, ideologizing the conflict. ${ }^{49}$

This may well apply in conditions of 'hot' war but in a more peaceful milieu, even if still beset by deep communal divisions, stasis, crisis, and occasional outbreaks of violence, a more nuanced appreciation of political ritual can be developed that uncovers a phenomenon we can conceptualise as adaptive commemoration. Reflecting on the discussion above in relation to Lebanon and Irish Republicanism in Northern Ireland we can observe that adaptive commemoration serves a number of functions in relation to the changes and tensions in a peace process or political 'unsettlement'; these relate to the maintenance of constituency cohesion, the legitimising of political shifts, and the signalling of potential relations with other communities. Adaptive shifts can thus see partisan memory partly retooled to peaceful acclimatisation. In doing so, adaptive commemoration comprises a triad of constitutive, ideological, and communicative roles, all processes of fundamental importance to political groupings, particularly in the welter of peace processing. Commemoration then, is not political window dressing or a social epiphenomenon. This fundamentally political triad is common to political commemoration generally, but in its adaptive form it deserves a closer inspection by those interested in the study or support of peacebuilding, for several reasons. Adaptive commemoration can be used to reassure and bind constituents (and possibly deflect

49 Daniel Bar-Tal, 'Collective Memory of Physical Violence: its Contribution to the Culture of Violence', in Ed Cairns and Mícheál D. Roe, (Basingstoke; Palgrave Macmillan, 2003), 89 
the criticism of spoilers) in transitions; and it can establish political continuity for an evolution from past violent resistance to present forms of peaceful advancement. It may also function to rhetorically signal a new approach to relations with other communities; although in this latter case it is worth pointing out that the rhetoric may mainly be used to acclimatise 'in group' constituencies to new tones in dialogue and modes of engagement. 'Out' groups may take the rhetorical signalling with a large pinch of salt, or it may be largely inaudible to them.

Partisan commemoration can thus be used to reorder or reframe the goals of political actors away from the more ideological frames of the past even if it is an invocation of that same past. This may seem counterintuitive, or at least very difficult, but in fact reaching for, or constructing, approval from a group's history may be a necessary condition for success in periods of negotiation and political shifts.

\section{Inclusive Commemoration as Peacebuilding - A Case Study of the 'Decade of}

\section{Centenaries'}

Partisan commemoration can be shaped to espouse narratives that have utility in underwriting peace. But there are difficulties for peacebuilding too, and we must remember its Janus face. It can also work to reinforce boundaries with fixed, simplified notions of the historical 'good' and the communal 'other'; and it can project support for militancy and violence that can repulse that 'other', inhibiting reconciliation, or at least damaging a sense of a new peaceful dispensation. In addressing these problems, much of the literature on engaging with memory in divided societies emphasises various lines of approach, which we can condense here as:

the need for commemoration to show multiple perspectives and interpretations; 
to engage with scholarship so that commemorative work has a firm historical and factual basis;

to realise that a most important part of commemoration is the process of engaging groups themselves;

to challenge stereotypical constructions of identities;

and that the aim of commemoration should be to deepen and broaden understanding of the past, and present identities. ${ }^{50}$

In amalgamating these approaches, we may conceptualise them as Critical-Inclusive Commemoration; a form of relating to the past which seeks to provide a pluralistic space for engagement whilst combining it with a measure of critical inquiry and reflection, informed by evidence and a more 'historical' method. The pluralising and critical aspects work to support one another, as a mixture of voices provides a mixture of interpretations; multiple interpretations may better allow a role for debate and evaluation, rather than the automatic delivery of fixed, familiar narratives. This opening out of a critical space, may encourage still wider engagement. We shall see that these broad points are reflected in the principles that have underlined some work of the 'Decade of Centenaries' within Northern Ireland, and which have met with some success. This makes it a most useful short case study of attempts to deal with difficult collective memories in the setting of ethno-national contestation.

\section{A Politically 'Live' Centennial: Unpacking the 'Decade of Centenaries'}

\footnotetext{
${ }^{50}$ Paige Arthur, 'Fear of the future, lived through the past: pursuing transitional justice in the wake of ethnic conflict' in Identities in transition: challenges for transitional justice in divided societies, ed. Paige Arthur (Cambridge: Cambridge University Press, 2011): 271302; Impunity Watch, Policy Brief: Guiding Principles of Memorialisation, (Impunity Watch: Utrecht, 2013); Marc Howard Ross, "The Politics of Memory and Peacebuilding." In Routledge Handbook of Peacebuilding ed. Roger Mac Ginty (London: Routledge, 2013): 91102
} 
Although there has been input and support from the UK, Ireland, and the power sharing government of Northern Ireland, the 'Decade' is not a centrally driven project or programme. Rather it can be pictured as an agglomeration of self-directed activity involving public bodies, political organisations, local authorities, 'single identity' community groups, cross community groups, libraries and museums, and the wider cultural sector. The 'Decade' covers the period of 1912 to 1923 , a period which saw not only many formative events in modern Irish history, but events which are regularly evoked, tapped, and commemorated in modern political discourse and party political commemoration. ${ }^{51}$ Events include the Ulster Covenant, the Easter Rising, The Battle of the Somme, the foundation of the Irish and Ulster Volunteers, the Anglo-Irish War, partition, the foundation of the Northern Ireland state and the Irish civil war; in short highly sensitive moments of mobilisation, violence, 'blood sacrifice', identity formation, and political fractures between and within ethno-national constituencies. The events may have happened one hundred years ago, but they have had a direct symbolic relevance, and indeed utility, to many political actors in contemporary Northern Ireland. Interpretations of these events vary markedly between ethno-national constituencies within Northern Ireland, yet the memory of these events is not simply politically charged and sensitive, but also politically valuable to actors. Centenary events of 2016 proved a particular case in point: 1916 saw the 'Easter Rising' a foundational moment in the Irish Republican project, and the demonstration of a mythic blood sacrifice. The year also saw the 'Battle of the Somme', when Ulster Unionists evoke a similar blood sacrifice narrative in relation to British patriotism and loyalty. The invocations of the 'Rising' and the Somme feature heavily within Irish Republican, and Unionist or Loyalist collective memory respectively. The memories then are valuable, - powerful symbolic and foundational

\footnotetext{
${ }^{51}$ Dominic Bryan, Mike Cronin, Tina O'Toole, and Catriona Pennell, 'Ireland's Decade of Commemorations: A Roundtable’ New Hibernia Review 17 (1), (2013): 63-86.
} 
moments that are supposed to reveal a given constituency's identity, values, and place in history. Consequently, much commemorative work is undertaken by current political groups to establish connection to, and continuity with, these historic moments, and the political groupings active at the time. There is a consequent risk that these commemorations can solidify boundaries and simplify identities in ways that conflict with cross community engagement.

\section{Principles and Activities of the 'Decade'}

As noted above, the period of the commemorative 'Decade' is an agglomeration of groups and activities, and there are enormous tensions at work in invoking memory from this period. The Community Relations Council (CRC), an 'arms-length' body of the Northern Ireland government saw challenges inherent in this invocation of memory, which would directly impact on its remit as a promoter of better inter-communal and inter-cultural relations in Northern Ireland; as such it has become an important actor in the 'Decade', though given its ethos and small size, by no means a directing one. The organisation's fear was that on many occasions commemoration had been used to 'ritualise and harden the boundaries between groups who have been in conflict', seize an ownership of historical events to further narrower political interests, and silence other narratives that may 'contradict or complicate' more partisan and simplified understandings of the past. ${ }^{52}$ The CRC was explicit in acknowledging that commemorated events were not simply part of a thorny history that would be fought out in the pages of historical journals, but had a continuing constitutive function for political communities in Northern Ireland having 'shaped the sense of British and Irish identity' in the

\footnotetext{
${ }^{52}$ Community Relations Council, Decade of Anniversaries Toolkit-Understanding our Past, Shaping our Future, (Belfast: CRC, 2013), 3-4
} 
recent past and present. ${ }^{53}$ Yet, as well as bringing challenges, the 'Decade' might also provide opportunity for engaging with clashing identities and narrower invocations of memory in the present: by seeking and facilitating the widest participation of actors, and inculcating an educational approach informed by historical research there was an opportunity to 'dispel myths' and make connections to 'hidden history' relating to gender, labour, and the international environment. In other words, useful mythologies might be counterpoised with historical research, and simplified forms of memory could be partly prised out of their ethnonational capsule.

Although not foregrounded in their analysis, what seems implicit in the Council's understanding is that the 'Decade' may act as a stalking horse in approaching the still more difficult memory of the modern 'Troubles' by providing 'important opportunities to develop our understanding of how marking important anniversaries should be fostered in the public space' ${ }^{54}$ Moreover, the CRC viewed the violent and revolutionary 'Decade' as a lens with which to interrogate contemporary understandings of 'what we mean by democracy and the nature of political change' which might have the 'potential to reinforce the development of political and civic culture'. We might further speculate that if the 'Decade' remains live history, readily reached for by ethno-national actors in framing politics and constituting identity, it nevertheless is of sufficient historical distance to allow for a more critical and reflective approach. Crucially, this might act as a small wedge, opening a chink in narratives of more recent conflict to allow similarly reflective scrutiny.

Seeing both challenges to, and openings for, memory as a peacebuilding exercise the CRC engaged a program designed to facilitate and guide a wide variety of organisations who were

\footnotetext{
${ }^{53}$ Community Relations Council, Remembering the Future - A Decade of Anniversaries Discussion Paper, (Belfast: CRC, 2011), 1

${ }^{54}$ Ibid., 3
} 
undertaking commemorations related to the decade. Funding formed part of the operation, but the main thrust came in the form of enabling a variety of different groups to network, compare approaches and possibly collaborate. The key intervention was the formulation of a series of 'Decade Principles' which the CRC (and its partner the Heritage Lottery Fund) sought to promulgate in workshops, public meetings, and one-on-one interactions with commemorating groups. The principles stated that commemorations should:

Start from the historical facts;

Recognise the implications and consequences of what happened;

Understand that different perceptions and interpretations exist; and show how events and activities can deepen understanding of the period. ${ }^{55}$ Engagement was open to all, but groups seeking funding support needed to follow these thematic and organising principles. Politically partisan groups were unlikely to buy in to such an arrangement, but many others were. Crucially, this did include single identity groups hailing from a particular ethno-national community, and local authorities which might be majority controlled by parties of a particular ethno-national stripe. A variety of cross community groups, trade unions, and broad based historical and cultural organisations made up the remainder of participants. This 'critical' commemoration took the form of plays, debates, lectures, classes, workshops and training events, installations, gatherings, and exhibitions. What resulted was a local catalysing of commemorative activity which clearly engaged with inclusive, reflective and critical approaches. Something of the historical method was thus mainstreamed into many local commemorations. Differing interpretations were foregrounded, myths challenged, internal diversity within 'bounded' communities revealed,

\footnotetext{
${ }^{55}$ Community Relations Council, Decade of Anniversaries Toolkit, 9.
} 
and a deeper contextualisation occurred, allowing themes relating to class, international influence, and gender to pierce ethno-nationally encapsulated understandings of history. ${ }^{56}$ Partisan forms of commemoration were not squeezed out (there was neither hope nor intention), but they were counterbalanced; the result was that public discourse was better primed to engage with a nuanced and reflective understanding of a politically valued and formative, but highly sensitive, past. Independent surveys of commemorating organisations have taken place which add corroboration to this view. It was revealed that many organisations understood the key features of their commemorative programmes as recognising difference, including multiple stories, allowing people to reflect, highlighting shared experiences, and humanising histories. Most were aware of the 'Decade' Principles, and it emerged that the best practice guidelines produced by the CRC were widely used. Two-thirds of organisations aimed to include multiple stories. ${ }^{57}$ A small majority of a 2017 survey reported that there was an increase in the number of participants who had a greater awareness of different cultures and felt more comfortable with acknowledging cultural diversity, whilst 50\% stated that participants were more open to discussion with those who have diverse or opposing opinions. A large majority (70\%) of organisations claimed that increased learning in relation to contested histories and commemoration itself was the overall effect of the commemorative work whilst $84 \%$ believed that their organisations were achieving better contextual understanding of the period within their audience. A direct impact on lowering inter communal tensions was realistically muted but still significant, with $35 \%$ of organisations believing that their organisations commemorative work had helped in this regard. ${ }^{58}$ The 'Decade' is only half complete; and caution is necessary given that the second

\footnotetext{
${ }^{56}$ For a partial selection see the case studies referenced in the Community Relations Council, Decade of Anniversaries Toolkit, 13-37

${ }^{57}$ SRM Consulting, Decade of Anniversaries, (Belfast: SRM Consulting, 2014); Stratagem NI, Report- A Review of Decade of Centenaries, (Belfast: Stratagem, 2017), 4-6 ${ }^{58}$ Stratagem, Review of Decade of Centenaries, 6
} 
half of the commemorative period will see events which reflect the living memory of the modern Troubles more closely, in terms of types of violence and their location. Yet, public and media discourse have as yet seen no sharpening of the memory of the period 1912-16 in a cultural battle between ethno-national groups despite their foundational importance. This is significant at a time of increased electoral polarisation in Northern Ireland.

\section{Conclusion: Approaches to Commemoration in Peacebuilding}

In examining commemoration in an ethno-national setting, we can see that partisan memory can be a hindrance to moves to improve inter-group relations through its sharpening of memories of conflict and opposition, and its ability to ideologise boundaries between groups, giving them a rather primordial depth. Yet, it can also serve as a pragmatic tool to acclimatise ethno-national groups to a more peaceful milieu even as it invokes past conflict. A problem remains that these processes can run on parallel tracks; adaptive commemoration might not sweep aside more ideological forms. Consequently, there still remains a need for the fostering of a more critical-inclusive form of commemoration; one which can counter balance stereotyping or one-sided narratives, and help to prime public discourse in ways which would defuse cultural triggers that might exacerbate polarisation. With that in mind, several propositions may be advanced in relation to partisan and inclusive commemoration, which might usefully inform interventions in relation to memory.

Partisan Memory can be a Reputational Shield that Facilitates Moves to Peace Those forming interventions should be aware that even partisan commemoration has its benefits for peacebuilding. It is used to keep a political constituency together during testing times providing a means for leadership engagement with its base that mollifies doubters by invoking continuity. It can thus be a tool against splits and spoiling; particularly those groups 
which attempt to yoke the memory of a militant past to the legitimisation of present day violent rejection.

Partisan Memory Can Send Messages Supportive of Peace Partisan commemoration can partially reshape its own narratives so that they are more congruent with a peace-seeking environment; and it can signal to its own base how to engage with communal 'out' groups in more productive or reconciliatory ways. Such commemorations bring key political activists and constituencies together in a setting which allows the sacral, legitimising sheen of past heroes and shared values to be woven into new political signals, giving the latter a more digestible form. External actors may view partisan commemorations as unhelpful invocations of past enmity, but if they want to discourage such commemoration, there may be costs attending the obvious benefits.

Critical and Reflective Approaches Remain Important Within ethno-nationally divided societies critical reflection should be facilitated in relation both to historical understandings, and the more communal or folkloric narratives of past conflict that percolate within partisan memory. It is too much to expect politically organised ethno-national commemorations to reshape themselves so that they fully unpick and re-examine narratives which continue to have a high emotional salience and political value for them. What is achievable is to facilitate and foster parallel forms of 'softer' commemoration which allow more for a more critical analysis of the past, in which both familiar and unfamiliar narratives circulate. This might entail challenging simplified understandings or stereotypes of political communities, movements and actors. It can involve spotlighting inconsistencies, mythologies, errors, or values now out of step with modern custom. This can be a difficult process; commemorative forms which allow for active enquiry would be well suited but can be labour intensive and difficult to design. Whatever their design, these parallel commemorations should have a relevance for, and the involvement of, local communities or they will not take. Partisan 
commemorations, backed by local political forces skilled in mobilisation and organisation, would overshadow them otherwise.

Complicate Identity Ethno-national commemoration may be abundant and may reflect the salience of ethno-national identity in a given political setting; but however powerful and important it is for an individual, it remains only one form of identification within social life. As such, purely partisan forms of memory can be reductive, particularly when in the hands of political elites and entrepreneurs. Portraying different forms of identification should thus also feature as an important aspect to be encouraged. This could attach to the pattern of parallel commemoration as outlined above. History telling and commemoration which makes adequate room for both gender and class may be important in this regard (indeed they often strongly intersect) as they can underline cross cutting histories. Ethno-national identity itself may not be blithely imagined away, but is supplemented in a manner which renders boundaries more permeable. Similarly, stories of those who crossed boundaries, or perhaps acted as 'good Samaritans', ${ }^{59}$ or even noting events which demonstrated co-operation by political leaders can give a more nuanced, and humane understanding of a difficult past. It would also be important to unpack monolithic understandings of ethno-national movementsand instead underline that these were movements in which there existed significant internal tensions.

Engage with Earlier Memories of Conflict First In a divided society riven by the memory of recent conflict it may be useful to take a more oblique approach to fostering commemorations supportive of peace. Interventions relating to commemoration might more easily engage with earlier histories of conflict between communities first. Establishing norms of historical veracity, encouraging debate, and ensuring that multiple points of view are expressed may be

\footnotetext{
${ }^{59}$ Dudai, Ron. "Rescues for Humanity: Rescuers, Mass Atrocities, and Transitional Justice." Human Rights Quarterly 34, no. 1 (2012): 1-38.
} 
easier when the events are at the limits of, or beyond, living memory. The events may still be of a high political value to groups, or formative of identity, and thus sensitised. But there is sufficient distance with which to robustly engage. Having insinuated a more reflective and critical approach to earlier ethno-national memory, it may partially travel 'up the line' to recent narratives of conflict.

Some of these points have been addressed before; but the 'Decade' has, and will continue to provide a test bed for their efficacy, and important information will be revealed about the limitations in developing inclusive commemoration too. The pragmatic and adaptive aspects of partisan memory provide both a problem and support for peacebuilding intervention; they are useful as they have reassured constituencies, and help keep the group together when the waters of peace become choppy. Yet, a corollary remains that they project narratives that may deepen boundaries and simplify history as a means to shape political identity, and in societies riven by ethno-national conflict, history is seldom simple. 